Society in 1938-an honour which he treasured as highly as any that came to him in the more academic sphere.

A great lover of argument, Small never failed to stimulate through his perennial heterodoxy, coupled with his impressive width of botanical knowledge. To those who knew him well he was the most kindly and generous of men, full of a humour which was wont to find its expression at times in the gertle teasing of authority, more particularly authority which was itself humourless.

$\mathrm{He}_{\theta}$ is survived by his wife, two sons and daughter. J. HesLop Hatrison

\section{Prof. D. R. Boyd}

David Runciman Boyd, who died on December 28, gave forty-one years service to university education in Southampton, and was one of the ablest of a very small and steadfast band whose work has made the University of Southampton possible. Born on February 26, 1872, he was the son of the minister of the parish of Mains, near Dundee. His father died when he was only one year old, leaving a widow and three young children in straitened circumstances. The family moved to Edinburgh, and young David attended the then rather spartan John Watson Institution during 1880-86. After a short period on the classical side of George Watson's College, he moved to Glasgow and in 1888 entered the University of Glasgow. He had a distinguished undergraduate career, gaining prizes in chemistry, natural philosophy and mathematics, and in 1892 was awarded the B.Sc. degree with honours in chemistry. With the Robert Donaldson scholarship he studied in Victor Meyer's laboratory at Heidelberg, acting as Jacobson's assistant for a year, and gained the Ph.D. degree. After about two years as demonstrator in chemistry, under Frankland, at the Mason College, Birmingham, he was one of five lecturers appointed in 1896 to the Hartley Institution, Southampton, with the object of bringing the teaching up to university standard. This was so far successful that the Institution became the Hartley University College, with a small and precarious Treasury grant, in 1902. It was largely due to Boyd and his colleague, John Eustice, head of the Engineering Department during 1892-1931, that the College survived the frequent crises of the first decade of this century.

Up to 1919, Boyd never had more than one academic assistant, and the major part of a heavy teaching programme fell on him. He was an excep. tionally clear and inspiring teacher: Prof. C. K. Ingold, a student at the College during 191I-13, writes: "he treated us to a most exciting exposition of the whole of Chemistry as a living, growing subject, rich in opportunity for the questing spirit. Werner's resolution of cobaltammines, and Knorr's and Kurt Meyer's work on ethyl acetoacetate came hot from the Annalen or Berichte, yet without sacrifice to the pattern of the lecture course as a whole. Everything was critically (and remarkably soundly) assessed, and some much publicized but unsound work dealt with severely". After 1920, with a somewhat larger staff, though still small by university standards, the teaching was maintained throughout at a very high level until his retirement in 1937.

Until about 1930, Boyd kept research going actively, despite very meagre resources. His name appears on some twenty papers, and another ten by his pupils are on lines initiated by him. He studied various aspects of the chemistry of aromatic compounds, and a series of papers on organic compounds of phosphorus is of particular interest. Two papers on the kinetics of reaction between sodium derivatives of phenols and ethylene oxides are still frequently quoted. He encouraged several other successful lines of research, in different branches of chemistry, in his department. He was awarded the D.Sc. degree of the University of Glasgow in 1902, and frequently examined for that University.

Boyd was invaluable in the administration of the College, in which he took a large part. He was chairman, later dean, of the Faculty of Science for many years, and vice-principal after the retirement of Prof. Eustice in 1931. He was tall, gentle and dignified, with courtly manners; he spoke and wrote clearly and persuasively, and spoke so little of himself that many of his colleagues were unaware that, over several years while holding the chair, he read for the Bar and qualified as a barrister of the Inner Temple. His unvarying maintenance of high academic standards, unselfishness and outstanding integrity earned the confidence of his colleagues; and he was much loved and respected in his own department. He married in 1909, and had two sons; but his later years were saddened by the death of both his sons in 1944 on war service, and his wife died last August. What the University of Southampton owes to him cannot be over-estimated; and he rendered notable services to chemistry both through his own researches and by the inspiration and sound training he gave to many generations of pupils, whose collective contributions to research and to teaching are an imposing monument to their teacher.

N. K. Adam

\section{Prof. P. N. Chirvinsky}

Petr Nikolaevich Chirvinsky was born on February 7,1880 , in Moscow in a family of a scientific worker. In 1902 he graduated from the University of Kiev. In 1909 he was appointed professor of applied geology in the Don Polytechnical Institute at Novocherkassk and finally in 1943 he became professor of petrology in the University of Molotov (formerly Perm). He died on June 21, 1955.

A petrologist and mineralogist by profession, Chirvinsky took all allied sciences as his province. In his fifty-three years of academic life, it is estimated that he published 380 papers and books comprising 6,760 printed pages, and covering such varied subjects as petrology, mineralogy, crystallography, meteoritics, geology, hydrogeology, astronomy, physics, chemistry and geochemistry. Of these the first four were his main preoccupation, and he has to his credit many published descriptions of igneous, metamorphic and sedimentary rocks, minerals and meteorites. $\mathrm{He}$ was particularly interested in the mineral composition of granites and other igneous rocks, and in this connexion he elaborated a method of "geometrical-chemical" analysis (1937) and published a book on the average composition of rock. forming minerals (1953). Another interest was the chemical composition and genesis of minerals, and one of his papers on a uranium mineral was published in English (Miner. Mag., 20, 287 ; 1925). More than eighty papers and notes were devoted to meteorites. He was also very much alive to the wider problems of cosmology and geochemistry. He was a modest and friendly man, and an excellent and inspiring t eacher.
S. I. TOMKEIEFF 